\title{
A magyar tervezésű és gyártású Levente II. kiképző repülőgép és légialkalmas másolatának megépítése wr.rosz
}

\section{HÁNY PÉLDÁNY KÉSZÜLT A LEVENTE II.-BŐL?}

A Repülőgépgyár Rt. által minimum 90 db-ban legyártott Levente II. típus - a maga kategóriáiában - ipartörténeti rekordnak számít. Ennél több magyar tervezésű motoros repülőgépet egyik hazai repülőgépgyár sem készített. ${ }^{142}$ Végezetül a magyar repülés történetében a Levente II. volt az a hazai motoros repülőgép, amelyre a legnagyobb megrendelés született: $140 \mathrm{db}$-os nagyszéria.

34. ábra. A Levente II. egyetlen megmaradt példánya, részben szétszerelve a Közlekedési Múzeum raktárában

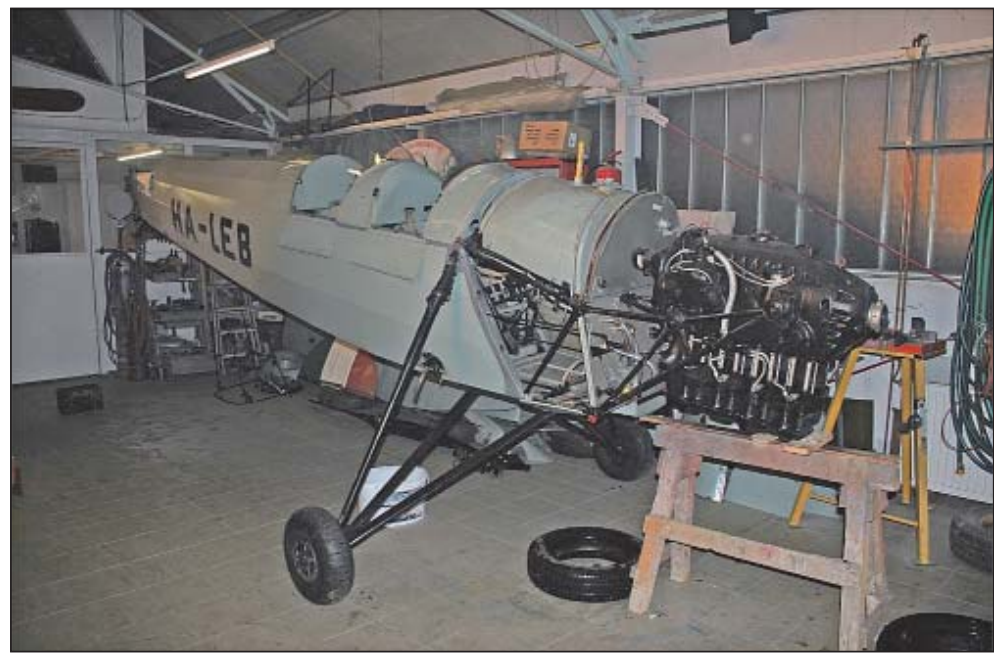

A Vérmezőre 1944 decemberében szárnyfelszerelés céljából került gépek közül csak az I.637 oldalszámú Levente II.-ről tudjuk pontosan, hogy elkészült és felszállt, azonban a többi 4 gép is elkészülhetett, ezért elképzelhető, hogy a legnagyobb legyártott darabszám 90 darab felett van. Ezt a feltevést erősíti, hogy további két olyan Levente II.-ről is előkerült forrás, amelyek 1944 decemberében a Vérmezőn voltak. Az egyik géppel Papp Ferdinánd Szabolcs Alajos szerelővel startolt el a Vérmezőről, majd szovjet légelhárító tüzbe kerültek és lezuhantak. ${ }^{143} \mathrm{~A}$ másik Levente II.-t, Vitéz Szentiványi János látta a Vérmezőn december 27 -én. ${ }^{144}$

A megrendelt $140 \mathrm{db}$ Levente II. mintegy 60\%-a készült csak el. A II. világháború körülményeitől sújtott magyar gazdaság nehézségei közepette megépített $90 \mathrm{db}$ Levente II. és a mátyásföldi repülőgépgyár létrehozása így is kiemelkedő teljesítményt jelent.

\section{A LEVENTE II. ALKALMAZÁSA A HMNRA-NÁL És a Magyar Királyı Honvéd LÉgieröben KIKÉPZŐ- ÉS FUTÁR REPÜLŐGÉPKÉNT}

A Levente II. repülőgépek egy részét feltehetően a REGVI-kben és bizonyíthatóan a Horthy Miklós Nemzeti Repülő Alapnál iskolázásra osztották be: a HMNRA 1943-ban a következő évi költségelőirányzatában $20 \mathrm{db}$ Levente II. üzemeltetésére készül fel. ${ }^{145} \mathrm{Az}$ első $10 \mathrm{db}$-os kisszériát 1943 őszén adták át Csepelen, ${ }^{146}$

5. táblázat. Legyártott Levente II. repülőgépek (1941-1944)

\begin{tabular}{|l|c|c|}
\hline 1941-ben elkészült a HA-NAT és HA-NAU prototípus & - & $2 \mathrm{db}$ \\
\hline 1942-ben elkészült a HA-NBQ és HA-NBR & - & $2 \mathrm{db}$ \\
\hline 1943 novemberében átadták az első kisszériát & $\mathrm{I} .551-\mathrm{I} .560$ & $10 \mathrm{db}$ \\
\hline 1944. április 7-i helyzetjelentésben már $20 \mathrm{db}$ elkészült szériagép szerepel & $\mathrm{I} .561-\mathrm{I} .570$ & $10 \mathrm{db}$ \\
\hline 1944. szeptember 27-i jelentés alapján $60 \mathrm{db}$ szériagép már átadásra került & $\mathrm{I} .571-\mathrm{I} .610$ & $40 \mathrm{db}$ \\
\hline 1944. október 20-i jelentés szerint újabb $10 \mathrm{db}$ szériagépet átadtak & $\mathrm{I} .611-\mathrm{I} .620$ & $10 \mathrm{db}$ \\
\hline 1944. december 20-i jelentésből kiderül, hogy további 15 szériagép repült ki Mátyásföldről & $\mathrm{I} .621-\mathrm{I} .635$ & $15 \mathrm{db}$ \\
\hline 1944. december 19-én jegyzőkönyv igazolja, hogy a Vérmezőn felszállt az I.637 szériagép & $\mathrm{I} .637$ & $1 \mathrm{db}$ \\
\hline A Levente II. típusból összesen elkészült 1944. december végéig minimum: & & $90 \mathrm{db}$ \\
\hline
\end{tabular}




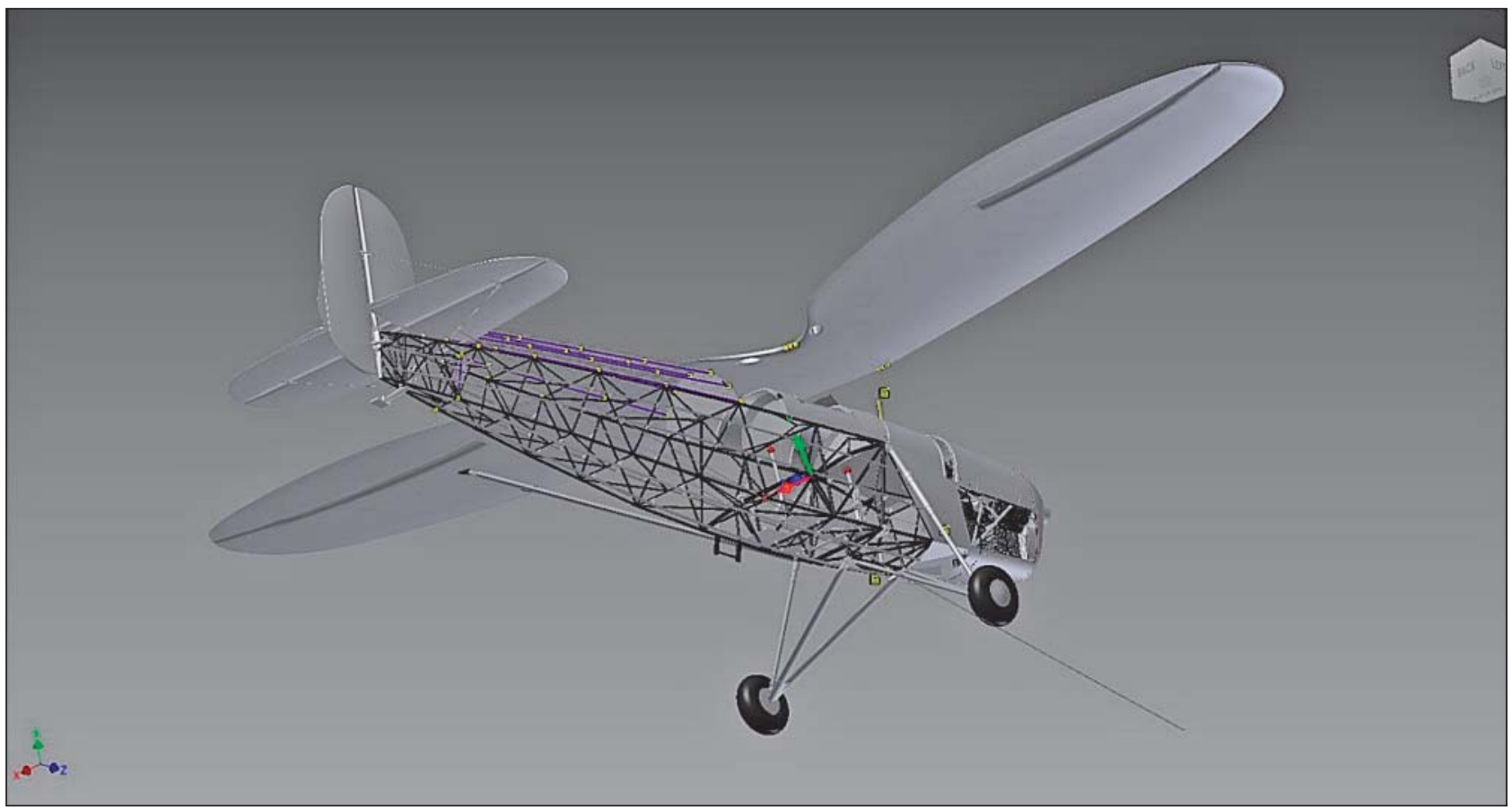

35. ábra. A Levente II. repülőgép szerkezetének számítógépes grafikája

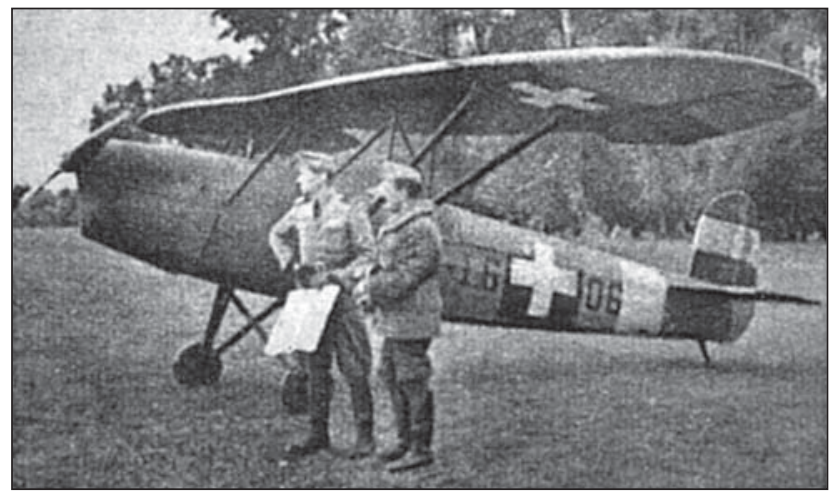

36. ábra. 1944-ben egy futárrepülőgépként alkalmazott Levente II.-vel új leszállóhelyeket keresnek a Dunántúlon

ezeket a Magyar Szárnyak 1943. december 15-i, 24. száma szerint Ferihegyre, tehát a HMNRA-hoz tervezték átrepülni, „hogy máris megkezdhessék szolgálatukat”. ${ }^{147}$ A Levente II. nagyszériából 1944 áprilisáig mindössze 20 db készült el $^{148}$ (valószínűleg ezeket mind a HMNRA-hoz osztották be). ${ }^{149}$

Az 1944 második felében fennálló háborús helyzetben a Levente II.-re már inkább mint futárgépre volt szükség. Ezt az is alátámasztja, hogy nagy mennyiségben Jungmannokat is, ${ }^{150}$ sőt Bestmannokat, ${ }^{151}$ de még EM.29-es iskolagépe$\operatorname{ket}^{152}$ is osztottak be futárszolgálatra. A Levente II. futárcélokra való beosztásáról rendelkező konkrét dokumentum nem ismert, így csak közvetett bizonyítékok alapján következtethetünk erre. Például Pintér Gyula naplójából derül ki, hogy 1945 tavaszán Pintér és Szőcs hadnagy a 101/3 vadászrepülő századtól egy Levente II. futárgépet repült át Veszprémből Kenyeribe, amikor szovjet II-2-es csatarepülőgépek támadták meg őket. Gépüket jelentős sérülés érte, de sikerült elmenekülniük az II-2-esek elől. ${ }^{153}$ A mai Ausztria területén az 1/II csatarepülő osztálynál használt I.626 lajstromú Levente II. futárgéppel Jankovich föhadnagy 1945. április 8-20. között többször is repült. ${ }^{154}$ Szintén ilyen célra vették igénybe azt az I.606-os oldalszámú Levente II.-t, amellyel a Magyar Szárnyak cikke szerint 1944 végén új leszállóhelyeket kerestek a légierő pilótái a DunántúIon. ${ }^{155}$ Kovács Ferenc a Mezőgazdasági Repülés 1989. évi 1. számában azt írja, hogy az I.606 az egyik Me 210 gyorsbombázó századnál volt; az I.615 a 101. éjszakai vadászszázadhoz került; az I.557, I.587, I.590, I.602 és I.620 jelzésű gépek a 101/III vadászosztálynál szolgáltak.

\section{A LEVENTE II., MINT VONTATÓ-REPÜLŐGÉP}

Winkler László „A magyar Repülés története” című könyvben a HA-NBQ és HA-NBR lajstromjelü Levente II.-ket is a HMNRA vontatógépeiként említi. ${ }^{156} \mathrm{Az}$ I. fokú kiképzés mellett szintén vontatásra is használták a Levente MWGben épült egyik példányát a HMNRA győri iskolájában Endes Gábor parancsnoksága alatt, még a '40-es évek elején. ${ }^{157}$ Emellett Winkler forrásai szerint a Levente II.-t 1944-ben az „RKI légideszant kísérleti részlegénél (Ócsára kitelepítve), valamint a Pápán folyó katonai szállító vitorlázó kiképzésnél vontatógépnek is használták."158

A Magyar Királyi Honvédség ejtőernyős zászlóaljának felállítását - és első, 1941. évi alkalmazásait - követően minőségi előrelépést a deszant-vitorlázógépek rendszerbe állítása jelentette volna a szervezetfejlesztésben. A német Gotha DFS-230-as típusú vitorlázó repülőgépek alkalmazási lehetőségei iránt élénken érdeklődött a magyar katonai vezetés is. ${ }^{159}$ Szy Tibor repülő főhadnagy egy részletes tanulmányt tett közzé e témában a katonai szaksajtóban. ${ }^{160}$ 1942-ben öt db 15 személyes R-21 típusú Rubik Ernő által tervezett tehervitorlázót rendelt a honvédség. ${ }^{161}$ Emellett Varga László és Szabó Imre megkezdte az RMI-10 típusú deszant-vitorlázó repülőgép kifejlesztését a Repülőműszaki Intézetnél. Amíg ezek a gépek gyártás alatt álltak, a pápai repülőtéren az ejtőernyős zászlóaljnál 1943 tavaszán két csoportban kezdték meg a vitorlázó-pilótaállomány képzését. ${ }^{162} \mathrm{Az}$ alakulat szervezetén belül a képzéssel öszszefüggésben létrehozták a kiképző szállító-vitorlázórepülő 


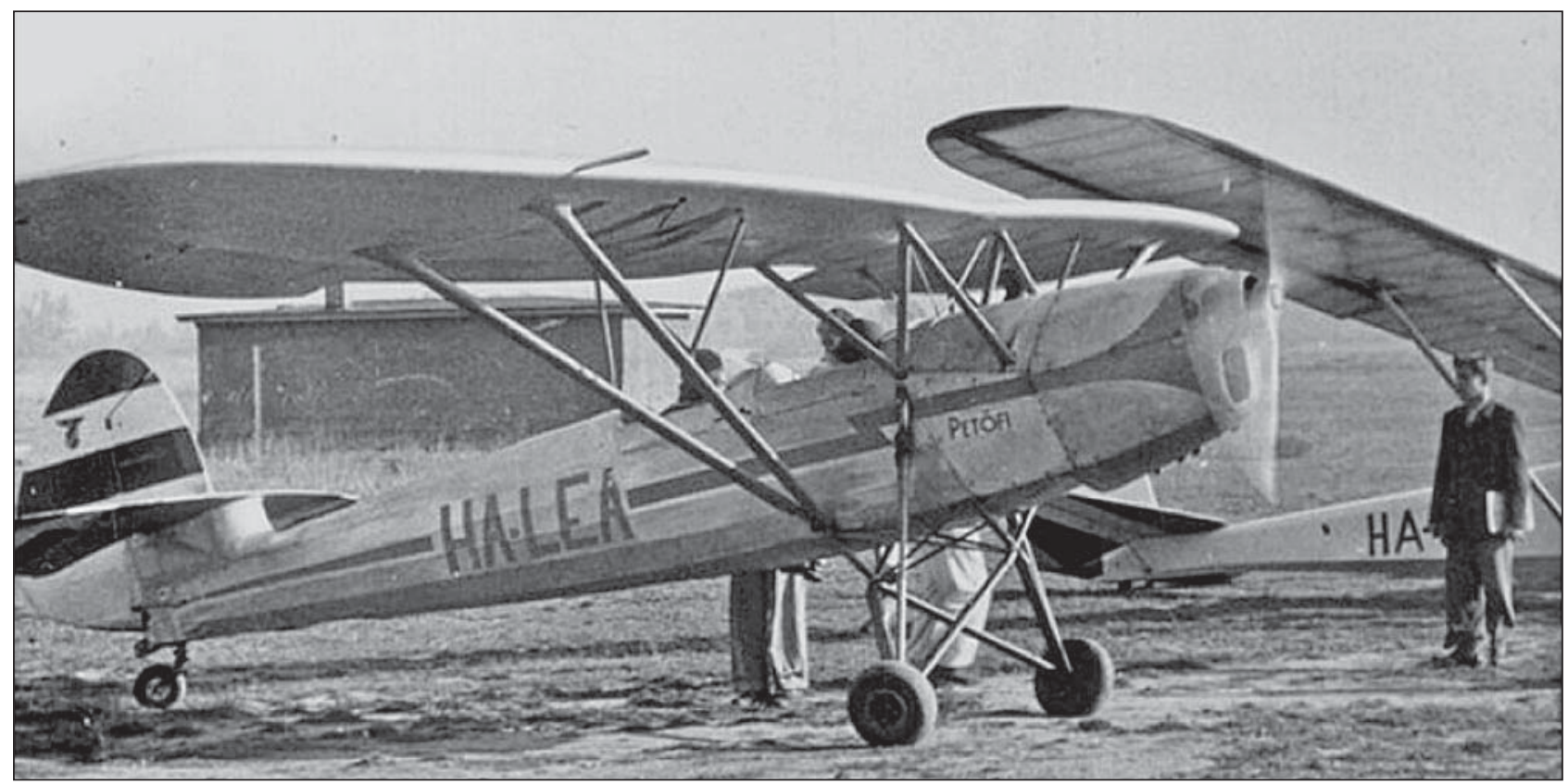

37. ábra. A Levente II. második világháború alatti vitorlázó-vontató tevékenységéről nem maradt fenn fotó, azonban ilyen tevékenység közben látható a Levente prototípusa, amelyet a háború után Pető́fi néven repültek

századot. ${ }^{163}$ Az alapfokú kiképzés végrehajtására elsősorban a pápai ejtőernyősök szállítórepülő-századát jelölték ki. Erre a célra elsősorban a kétkormányos Cimbora típusú vitorlázógépeket használták, amelynek a tömege a kor vitorlázógépeihez képest jelentősnek mondható, így a típus vontatására a Levente II. válhatott be a legjobban. A kiképzés során alkalmazott gyakorló vitorlázó repülőgépeket 5 db Tücsök, 5 db Vöcsök, 5 db Pilis B, 2 db Rubik Móka, $10 \mathrm{db}$ kétüléses Cimbora deszant-kiképző vitorlázógép, $5 \mathrm{db}$ nagy teljesítményű Kevély és $2 \mathrm{db}$ műrepülhető $\mathrm{M}-22$ típusú vitorlázó-repülőgépet - az M-22-es kivételével szintén Rubik tervezte és gyártotta esztergomi üzemében (Aero Ever Kft.). ${ }^{164}$ Továbbá 3 db DFS Kranich deszant-vitorlázó kiképző repülőgép is beérkezett Németországból.
A pápai kiképzés 1944 késő nyaráig tartott. ${ }^{165}$ Egy másik ágon, a légierő-parancsnokság részéről 1944 első felében, Németországban kapott vitorlázórepülő nappali és éjjeli vontatásos kiképzést további 3 fő, akiket később hazai területen oktatóként alkalmaztak. ${ }^{166}$ Hazatértük után Ócsán folytattak deszant-vitorlázó kiképző repüléseket, ahol vélhetőleg szintén kiképeztek 10-15 főt. ${ }^{167}$ 1943-44-ben Ócsán, a Repülőkísérleti Intézet telephelyén (illetve később Szolnokon is) folyt a vitorlázórepülőgép-vezető kiképzés. ${ }^{168}$ Ócsán - Winkler adatai szerint - a Levente II. vontatott, azonban az 1944-ben a szolnoki repülőtéren a nehezebb DFS-230-as deszant-vitorlázókkal végzett haladó kiképzés során a vitorlázógépeket már Heinkel He 111-es repülőgépek vontatták - a Levente II. ennél a képzésnél nem kapott

38. ábra. Levente II. vitorlázó repülőgépet vontat a háború után Győrben

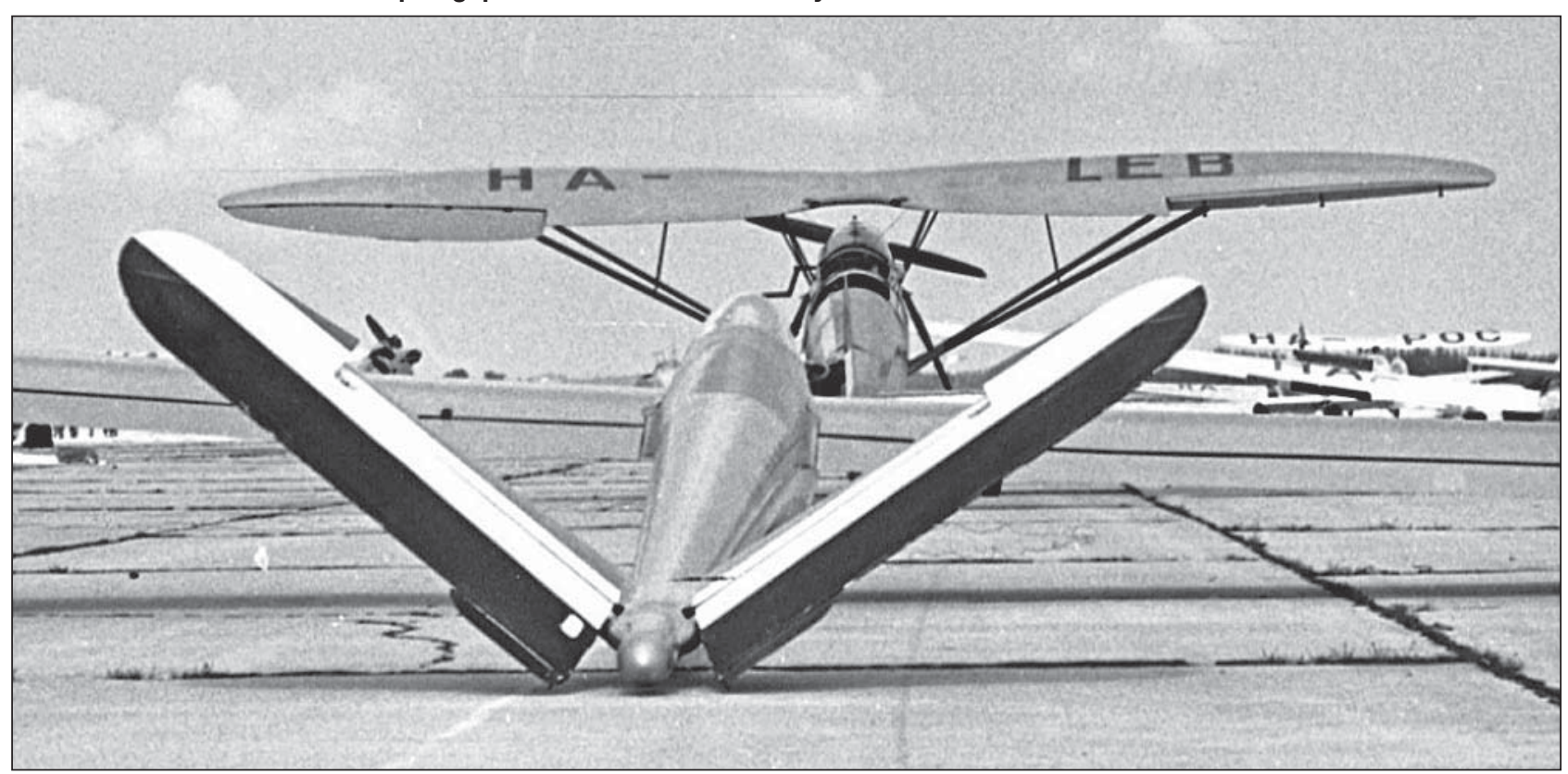




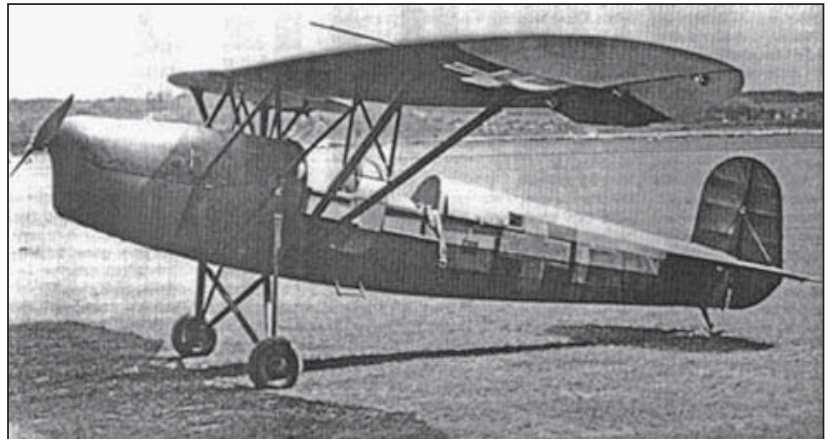

39. ábra. A Svájcba kirepült Levente II., a landolás után

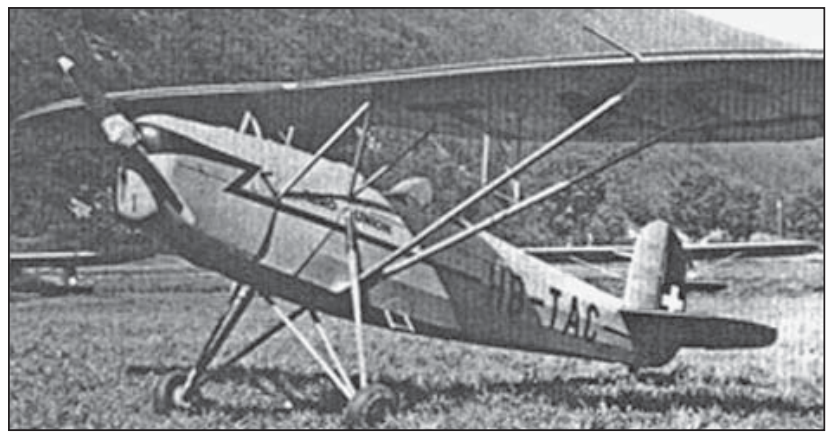

40. ábra. A HB-TAC jelzéssel honosított svájci Levente II.

szerepet. Habár a Levente II. nem volt alkalmas a DFS 230as harci deszant-vitorlázó vontatására, a sokkal kisebb tömegű DFS Krainch deszant-kiképző, illetve a Rubik kiképző vitorlázógépek - összesen 37 db különféle vitorlázó repülőgép - vontatására alkalmasnak bizonyult.

Az 1944-es év végéig a megrendelt Rubik R-21-es tehervitorlázók nem készültek el. Ugyanakkor a német szövetséges 1945 elején 15 db Gotha Go-242-es tehervitorlázót, illetve több DFS-230-as szállító-vitorlázógépet adott át a magyar szövetségesnek, azonban bevetésüket - a je- lenlegi források szerint, annak ellenére, hogy legalább mintegy 30 fő kiképzett magyar deszant-vitorlázó pilóta állt rendelkezésre ekkor - kizárólag német személyzettel, anyagi utánpótlás (lőszer, élelmiszer) biztosítása céljából hajtották végre Budapest légi ellátása során.

A Levente II. sokoldalú felhasználhatóságát jelzi, hogy vontatógépként is bevált. A Levente II. a vontatásos kiképzéseiben jól helytállt, mivel az erre jellemző intenzív felhasználás során (folyamatos, legalább 10-15 vontatás motorleállítás nélkül) nem kellett a csillagmotoros vontatógépekre jellemző süllyedési korlátozásokat betartani, mivel a Hirth motor visszahülésre kevésbé volt érzékeny, mint a csillagmotorok. ${ }^{169}$ Repülési tulajdonságai miatt alkalmas volt arra, hogy a háború előtt megjelenő gyorsabb szárnyprofillal rendelkező teljesítmény-vitorlázógépeket is vontathassa. A jó vontatóképesség oka, hogy kis tömege és jó gyorsulási képessége miatt vontatásban hamarabb elemelkedik, és képes volt megfelelő emelkedés mellett a teljesítmény-vitorlázógépek (pl. M-22-es) számára megfelelő 100 $\mathrm{km} / \mathrm{h}$ tartására. ${ }^{170} \mathrm{~A}$ vitorlázó-teljesítményrepülések során gyakran előforduló terepre szállás során szintén előnyös volt a Levente II. egyedi kialakítása. ${ }^{171} \mathrm{Az}$ idegen terepre történő leszállás során létfontosságú, hogy a leszállómező fölött alacsonyan, kis sebességgel végigrepüljön és feltérképezze a veszélyt jelentő akadályokat. A Levente II. parasol kialakításából adódóan nagyon jó a kilátás lefelé, így ez a feladat nagy biztonsággal végrehajtható. Terepre szállás során a repülőgép további előnye, hogy kis sebességgel is kilebegtethető, kifutási úthossza rövid, futóművének jellegéből adódóan előkészítetlen terepről is használható.

Ilyen módon a Levente II repülőgép jelentős szerephez jutott a HMNRA és a Magyar Királyi Honvéd Légierő vitorlázó képzésében (majd a háború után is sokáig alkalmazták vitorlázó-vontatóként a típust. ${ }^{172}$ ) A Levente gyártójának további hozzáiárulása volt a deszant-vitorlázó programhoz, hogy az Uhri cég megkapta a Müegyetemi Sportrepülő Egyesület által tervezett M.22 típusú vitorlázó-repülőgép gyártási jogát is. ${ }^{173}$

\section{1. ábra. Siemens csillagmotorra átalakított gép Svájcban}

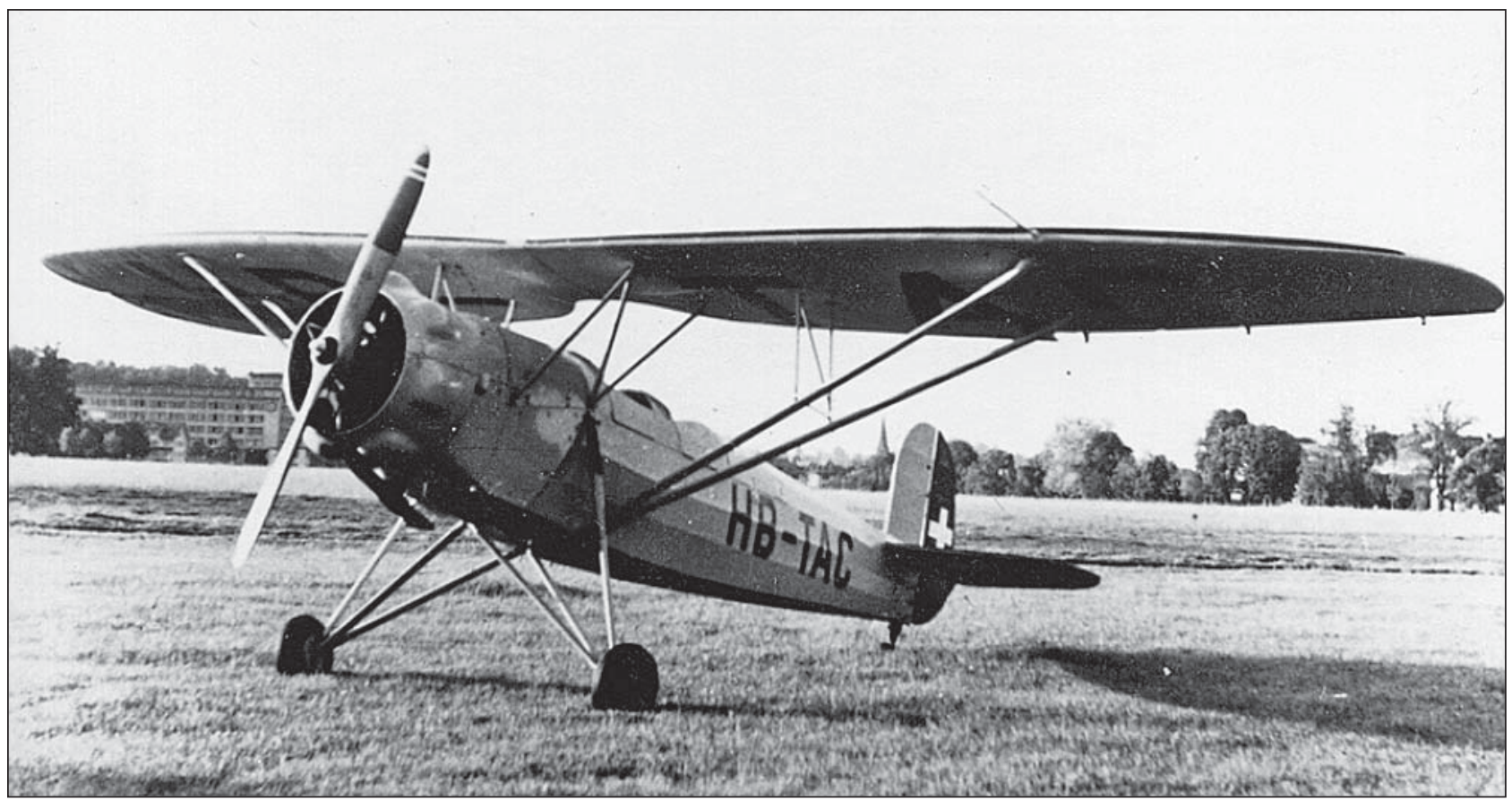




\section{A LEVENTE II. REPÜLÖGÉPEK ÉS A REPÜLÖGÉPGYÁR HELYZETE 1945-BEN}

1945. április 12-én a szovjet hadsereg elől már Ausztriáig visszavonult, széteső félben lévő magyar alakulatok egyikének két pilótája, Környei János és Vajda Szabó Zoltán Linz repülőteréről Svájcba szöktek egy széria Levente II.vel. Indulás előtt a gép lajstromjelét átfestették, a dübendorfi landolásuk során készült jegyzőkönyv szerint a gép törzsén F.9+ZC oldalszám állt, ${ }^{174}$ mely feltehetően eredetileg I.5+70, azaz I.570 volt. ${ }^{175}$ Két év múlva a grencheni Aero Unionnál alapos átvizsgálás után berepülték a gépet - itt a farokcsúszót farok-kerékre építették át. A magyar hatóságoktól beszerzett típusdokumentáció alapján, 1948-ban a svájci Levente II.-t HB-TAC jelzéssel vették lajstromba.

A Repülőgépgyár Rt. vezetése több ízben tett kísérletet a kitelepített ingóságok felkutatására, de nem jártak sikerrel. ${ }^{176} \mathrm{~A}$ gyár összes gépi berendezése, anyagkészlete,

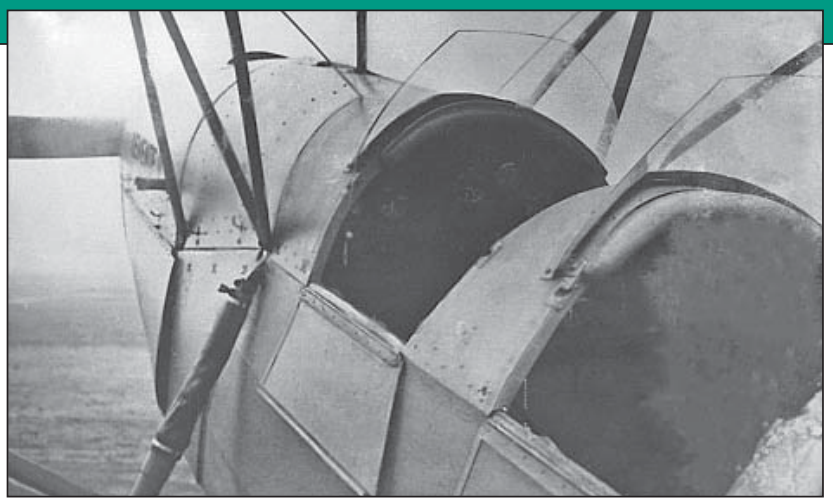

42. ábra. Levente II. repülögép pilótakabin-része a korabeli múszerekke

műszaki dokumentációja, a Levente II., a Bestmann és a kísérleti gépekhez készített szerszámok jelentős része odaveszett vagy eltúnt a háborúban, így a repülőgépgyártás ellehetetlenült, és a Repülőgépgyár Rt. ezután már csak névlegesen létezett tovább. ${ }^{177}$

\section{JEGYZETEK}

142 A darabszámot tekintve a Levente II. a második helyen áll a WM-21 Sólyom után, melyből azonban három különböző magyar repülögépgyár együttesen állított elő összesen 128 db-ot. Haditechnika. 1997, 3. szám. Winkler László: Repülőgépgyártás a győri MWG Rt. üzemeiben, 1. rész.

143 Magyar Szárnyak évkönyv. XXI. évf., 21. szám. Hungarian Aero Museum. Toronto, 1992. 249. o. Papp Ferdinánd: Vigyázott rám a jó Isten.

144 Vitéz Szentiványi János: Rendhagyó karácsony. Magyar Szárnyak Évkönyv 1991-es szám, továbbá a www.blog.hu internetes oldal

145 HL HM 1944 Eln. 34. oszt. - A HMNRA 1944 évi költségvetése, dátum nélkül

146 Magyar Szárnyak. 1943. december 15., 24. szám. Figyelő: Minden izében magyar munka gyümölcse a Levente II.

147 Magyar Szárnyak. 1943. december 15., 24. szám. Figyelő: Minden ízében magyar munka gyümölcse a Levente II.

148 MNL OL Z.516 2. cs. 25. t. - Repülögépgyár Rt. helyzetjelentés, 1944. április 7.

149 HL HM 1944 Eln. 34. oszt. - A HMNRA 1944 évi költségvetése, dátum nélkül

150 Becze Csaba Az arany sas nyomában (2008).

151 Bonhardt Attila - Sárhidai Gyula - Winkler László: A Magyar Királyi Honvédség fegyverzete. Zrínyi Kiadó. Bp., 1992. 399. o.

152 Uo. 404. o.

153 Pintér Gyula naplójának részlete. Magyar Szárnyak Évkönyv, illetve Punka György gyüjteménye

154 Punka György gyűjteményéből - Jankovitsch hadnagy repülési parancsa az I.626 Levente II.-vel, 1945. április 8.

155 Magyar Szárnyak. 1944. október 15., 20. szám. Kováts Attila: A Honvéd Légierők harcai.

156 Csanádi Norbert - Nagyváradi Sándor - Winkler László: A magyar repülés története. 2., bővített kiadás. Műszaki Könyvkiadó. Bp., 1977. 351. o.

157 MNL GyMSMGyL XI.15 456. d. - Endes Gábor teherautót igényel a győri Aero Club-hoz tartozó Levente elszálításához, 1942. november 9. és MNL GyMSMGyL XI.15 456. d. - Endes Gábor fegyelmi ügye, 1. sz. melléklet, 1942. november 10. És Dr. Barla Ferenc (szerzői munkaközösségben): Győr és a repülés. MHSZ. Győr, 1988. 30. o., 45. o., 56. o.

158 Bonhardt Attila - Sárhidai Gyula - Winkler László: A Magyar Királyi Honvédség fegyverzete. Zrínyi Kiadó. Bp., 1992. 400. o.

159 Egy németországi tapasztalatszerző útra is sor került. A csoport hazatérése után rövid idővel, 1942 őszén a németek egyik áttelepülő kötelékéből a vontatókötél elszakadás miatt egy szállító vitorlázó-repülőgép kényszerleszállást hajtott végre a Pápa melletti Kéttornyúlak egyik lucernaföldjén. Segítségükre, néhány katonával Szijjártó Ferenc mérnök százados és Pávay Endre föhadnagy ment ki, akik hosszas győzködés után a repülőtérre vitették a gép pilótáit, míg ők az őrzés biztosítása ürügyén tüzetesen átvizsgálták a repülőgépet. A magyar katonai ejtőernyőzés története. Főiskolai tankönyv, ZMNE, 1999.

160 Magyar Szárnyak 1940. május 1-ei számában

161 Turcsányi Károly - Hegedűs Ernő: A magyar légideszant-csapatok alkalmazásának, haditechnikai eszközeinek és szervezetének fejlődése (1933-1945) II. rész Katonai Logisztika 2006. évi 4. sz. 159. o.

162 Az első csoportba a szállítórepülő század 5 nagytapasztalatú repülőgép-vezetője és Tassonyi Edömér ejtőernyős százados, míg a másodikba 9 fő repülő és ejtőernyős sorkatona került, összesen 15 fő.

163 M. Szabó Miklós: A Magyar Királyi Honvéd Légierő a második világháborúban. Zrínyi, Budapest, 1987. 177. o.

164 Bonhardt Attila - Sárhidai Gyula - Winkler László: A Magyar Királyi Honvédség fegyverzete. Zrínyi Kiadó. Bp., 1992. 423-427. o.

165 Vitorlázórepülőgép-vezető képesítést nyert: Sági László főhadnagy, Görgényi Kálmán hadnagy, Szántai Alajos hadnagy, Szennik Dezső zászlós pilóták, Szíjjártó Ferenc műszaki mérnökszázados, Tassonyi Edömér ejtőernyős százados és 7 fő sorállományú katona.

166 Zalán Ervin főhadnagy és Béles Tibor főhadnagy, valamint Tömösváry Gábor hadnagy.

167 Ebben részt vett Skyta Romuland ismert vitorlázórepülő oktató is.

168 Farkas Gábor - Lajtai János: Székesfehérvár repüléstörténete I. MVRE. Fejér megyei szervezete, Székesfehérvár, 1979. p.103. Sági László: Vitorlázórepülő kiképzés Pápán 1943-44-ben. Magyar Szárnyak 1990. Sági repülő főhadnagynak, az ejtőernyős szállító század egykori parancsnokának cikke.

169 Pl.: Siemens-Halske Sh11, vagy Svecov M11.

170 Emiatt a típust nem véletlenül választották a fém építésű (és majdnem lamináris profilú) kísérleti Győr 2 vontatására a háború után.

171 Terepvontatás során a vontatógép pilótája egy ismeretlen, általában mezőgazdasági művelés alá vont idegen terepre kénytelen leszállni, majd onnan a vontatmánnyal felszállni.

172 Az első Leventével a háború során Győrben iskoláztak és vitorlázóvontatást végeztek. Győr és a repülés. MHSZ kiadás. 1988. 30., 45. és 56 . o.

173 Az Uhri cég MSrE-tel kötött szerződése M.22 vitorlázógépek gyártására és forgalmazására, 1939. augusztus 1.

174 Punka György gyűjteményéből, Bericht - Svájcba szöktetett Levente II. jegyzőkönyve, 1945. április 12.

175 Theo Wilhelm: Fremde Flugzeuge in der Schweiz. 2. kiadás. Magánkiadásban, 2006. 397. o.

176 MNL OL Z.516 2. cs. 23. t. - Elhurcolt Javak Kormánybiztosságának írt levél, 1945. október 16. És MNL OL Z.517 9. cs. 50. t. - A Külföldre Hurcolt Magyar Nemzeti Vagyon Kormánybiztosságának írt levél, 1946. március 19.

177 MNL OL Z.516 1. cs. 15. t. - Repülőgépgyár Rt. igazgatósági ülésén készült jegyzőkönyv, 1947. november 10. 